STONE CENTER ON SOCIO-ECONOMIC INEQUALITY

WORKING PAPER SERIES

No. 12

Inequality as Entitlements over Labor

Paul Segal

March 2020

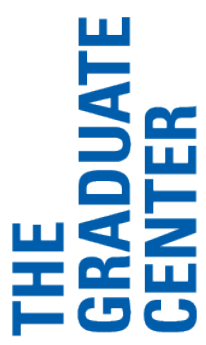




\title{
Inequality as Entitlements over Labor
}

\author{
Paul Segal \\ Department of International Development, King's College London \\ and International Inequalities Institute, London School of Economics \\ paul.segal@kcl.ac.uk
}

This version: March 2020

\begin{abstract}
The modern study of economic inequality is based on the distribution of entitlements over goods and services. But social commentators at least since Rousseau have been concerned with a different aspect of economic inequality: that it implies that one person is entitled to command another person for their own personal ends. I call this inequality as entitlements over labor. I propose to measure entitlements over labor by calculating the extent to which top income groups can afford to buy the labor of others for the purpose of their personal consumption. Unlike standard inequality measures, this measure is not welfarist, but instead has its normative basis in relations of domination, hierarchy and social status between people. I estimate entitlements over labor in three high-inequality and two low-inequality countries and argue that inequality as entitlements over labor is socially and politically salient, capturing a side of inequality neglected by standard measures.
\end{abstract}

SER key words: Inequality, income distribution, socio-economics, elites, hierarchy

JEL codes: D31 Personal Income, Wealth, and Their Distributions; D63 Equity, Justice, Inequality, and Other Normative Criteria and Measurement

Acknowledgements: For helpful comments and discussion or for generously providing data I thank Facundo Alvaredo, Tony Atkinson, Ingrid Bleynat, Alice Evans, Francisco Ferreira, Stephen Jenkins, Olle Hammar, Julian Messina, Branko Milanovic, Suresh Naidu, Filip Novokmet, Aaron Reeves, and Daniel Waldenström. I gratefully acknowledge support from the Leverhulme Foundation and the Joseph Rowntree Foundation. I also thank Carmen and Gemma, who have been indispensable to la felicidad de la casa, and without whom this work (and much else) would not have been possible. 


\section{Introduction}

The study of economic inequality is based on distributions of income or expenditure, with money as the numeraire. While the social and political consequences of inequality have been interrogated from a variety of angles, its measurement has not gone beyond this assumption that economic inequality between two people means differing entitlements over a representative basket of goods and services. The empirical study of inequality has thus neglected a dimension discussed by social commentators at least since Jean Jacques Rousseau: that it also implies that one person may have the entitlement to command another person. Rousseau (1762: 45) wrote that, "by equality, we should understand, not that the degrees of power and riches are to be absolutely identical for everybody; but that... in respect of riches, no citizen shall ever be wealthy enough to buy another, and none poor enough to be forced to sell himself." Rousseau points to the interpersonal or relational dimension of economic inequality: that it means that the rich are able to command other people for their own consumption purposes. He describes the relationship that ensues as domination and servitude.

Building on Rousseau's insight, this paper develops an interpretation of economic inequality as entitlements over labor. It refers to the fact that inequality can mean that the rich have the economic entitlement to command other people's labor for their personal consumption, where an entitlement to $x$ is the right and opportunity to command $x$ for one's own purposes, whether or not one chooses to exercise it (Sen 1984, p. 497). I propose a measure $E$ of this form of inequality defined as the ratio of the disposable incomes of a top income group - such as the top $1 \%$, or top decile - to the cost of employing a typical worker (where "typical" is to be defined). If the average disposable income of individuals in the top $1 \%$ is sufficient to employ 15 typical workers, then they have entitlements over the labor of 15 people. Where the income share of the top $1 \%$ or top $10 \%$ measures their relative command over resources, 
entitlements over labor measures their command over other people. Since the rich do not spend all their income on employing people to serve them, one can also interpret the inverse of this ratio as a measure of the affordability to the rich of employing someone, as a fraction of their income: in this case someone in the top $1 \%$ would need to spend only $1 / 15^{\text {th }}$ of her income in order to have another person working full time catering to her desires and needs.

The use of labor as numeraire was famously proposed by Adam Smith (1776: 47), who wrote, "Every man... must be rich or poor according to the quantity of that labor which he can command, or which he can afford to purchase." Yet Smith had a very different focus from Rousseau. Where Rousseau was concerned with command over labor as command over people, for Smith it was a means to an end: labor was important as an input to producing "riches" more broadly, or "the necessaries, conveniences, and amusements of human life". ${ }^{1}$ Labor as a numeraire in this sense, and labor theories of value more broadly, have fallen out of favor, in part because of labor's substitutability by other inputs to production. But this substitutability does not affect Rousseau's perspective: as I discuss later, while labor as a productive input is often substitutable, there are important ways in which command over labor as command over a person is not.

This new approach to inequality measurement complements the recent wave of inequality research that has used novel sources of data to uncover incomes at the top of the distribution. $^{2}$ This research has led to a dramatic expansion in our empirical knowledge of economic inequality. But so far there has been no corresponding resurgence in research on how to interpret economic inequality. A former president of the American Sociological Association has called for closer examination of "the nature of inequality itself to take into account its multidimensional complexity" (Ridgeway 2014, p. 2), while a former president of the

\footnotetext{
${ }^{1}$ Smith argued that the division of labor means that nobody produces everything that they want to consume, so that being able to enjoy goods and services in general therefore requires command other people to produce and supply them.

${ }^{2}$ See the World Inequality Database and references therein, wid.world.
} 
American Economic Association has similarly argued we need to investigate further "what kind of inequality matters" (Deaton 2019). Inequality as entitlements over labor provides a new perspective on the significance of the top incomes that have been the focus of the new inequality agenda. It connects top incomes with concerns over domination and republican freedom elaborated by political philosophers following Rousseau, and concerns over social hierarchies and relational inequality highlighted by sociologists following Weber.

Beyond its theoretical relevance, I provide evidence for the social and political salience of inequality as entitlements over labor. Socially, entitlements over labor are fundamental to conceptions of the upper middle class lifestyle in many countries, via the employment of domestic service. Second, and in part because of this, entitlements over labor are salient to political-economic conflict: typical wages represent income for the majority, but a consumption price for the rich and upper middle classes. This implies a direct conflict of interest between wage earners on the one hand, and the rich and upper middle classes who enjoy labor entitlements on the other hand. I conjecture that this helps to explain recent political developments in Brazil, where upper income groups did not lose either income shares or purchasing power in general but, because of rising wages lower down the distribution, did lose command over the labor of their poorer compatriots.

Section 2 describes the normative basis of inequality as entitlements over labor and contrasts it with the standard normative basis of inequality measurement. Section 3 discusses questions of measurement and presents estimates in a selection of middle- and high-income countries. Section 4 discusses the social and political salience of entitlements over labor. Section 5 concludes and suggests further areas in which this approach may bring new insights. 


\section{The normative basis of inequality measurement}

\section{Economic inequality and social welfare}

As Atkinson and Bourguignon (2000: 41) have noted, "income distribution may be considered the normative economic issue "par excellence'." Despite this, the normative basis for the measurement of economic inequality remains remarkably narrow, dominated by Dalton's (1920) and Atkinson's (1970) economic welfarism. Dalton argued that inequality measures are of interest primarily because of what they tell us about the amount and distribution of "economic welfare". Atkinson (1970) showed that for any Lorenz consistent measure of inequality, this normative interpretation is based on an underlying symmetric and concave social welfare function (SWF) specific to that measure.

On this basis, Atkinson showed that standard measures of inequality can be viewed as measures of distributional inefficiency in the production of social welfare: for any standard SWF, it would take less aggregate income to produce the same level of social welfare if that income were distributed equally, than unequally. Formally, Atkinson defines the equally distributed equivalent income $y_{\text {ede }}$ as the average income required to achieve the existing level of social welfare, if income were distributed equally. Strict concavity of the social welfare function implies that $y_{\text {ede }}<\mu$, where $\mu$ is the actual mean income. Thus $I=1-y_{\text {ede }} / \mu$ is a measure of inefficiency in the production of social welfare. A value of $I=0.3$, for instance, means that the current level of social welfare could be achieved with $30 \%$ less income, if that income were equally distributed.

The argument that inequality implies inefficiency in the production of social welfare is an important reason to care about inequality. It also provides a powerful counter to the common argument that concerns with inequality are driven by envy, because it emphasizes that one can object to the incomes of the rich not because they are rich per se, but because their incomes come at everyone else's expense. As Tawney (1913) put it, "what thoughtful rich people call 
the problem of poverty, thoughtful poor people call with equal justice the problem of riches." Moreover, despite its foundational role in the study of economic inequality, the argument remains underappreciated outside the narrow confines of economic inequality scholarship. ${ }^{3}$

Nevertheless, this approach has limitations. Sen (1997: 385ff) points out that an individual's economic welfare depends on numerous factors beyond their income, and these factors may imply different rates of transformation of income into well-being. For instance, an unfavourable environment, or an illness or disability, might reduce that rate of transformation. A second limitation is that, by applying the same price deflator to all incomes, it assumes a representative consumption basket for all individuals in the distribution. But this does not reflect real expenditure patterns: the rich buy a different set of goods and services than the poor, implying that ideally one would use different deflators at different points of the income distribution. ${ }^{4}$

A third and more profound drawback of this framework is that it is Paretian in incomes, meaning a rise in income for anyone (holding other incomes equal) will increase social welfare. A rise in the incomes of the very richest individuals will increase social welfare, even if at the same time it increases the inefficiency with which income is converted into social welfare. This ignores the possibility that a rise in inequality driven by rising incomes of the richest individuals may itself produce undesirable social outcomes.

\footnotetext{
${ }^{3}$ For instance, O’Neill's (2008) detailed philosophical discussion of inequality does not include it among his list of reasons to care about inequality.

${ }^{4}$ Deaton (1998: 43) estimated that in the US the CPI correspondss to expenditures at the 75th percentile of the expenditure distribution, and cites Deaton and Muellbauer's (1980, Table 7.1) finding that inflation was two points higher for the poor than for the rich in Britain in 1975-76. Moretti (2015: 66) found that housing costs grew faster over 1980-2000 for college graduates than for high school graduates.
} 


\section{Inequality, hierarchy, and domination}

Political philosophers and sociologists have raised a different set of concerns over inequality from those that motivate economists. ${ }^{5}$ Rousseau argued that the social bad caused by economic inequality was domination and servitude, because the power of one person to "exact obedience" from another implied "bonds of servitude" leading to "misery". ${ }^{6}$ Max Weber was concerned with inequality in power and in social status, associated with "negative or positive privileges" (Weber 1922: 305). Entitlements over labor speaks to both of these concerns, and I will argue it provides a link between these different conceptions of inequality: it is a mechanism for transforming inequality in resources into power over other individuals, leading to inequality in social status.

Atkinson (2007: 21-22) himself - fully aware of the limitations of the Dalton-Atkinson framework - suggested that studying the rich was normatively important because income provides "power" through "command over people". The ability to command another person is what republican theorists, following Rousseau, refer to as domination. To be dominated means being required to obey a will other than one's own (Neuhouser 2013); someone who is dominated is subject to arbitrary control and interference, where arbitrary means "chosen or not chosen at the [dominating] agent's pleasure" (Pettit 1999, p. 55). ${ }^{7}$ Modern republican theorists define republican freedom as freedom from domination, and the key objection to being dominated is not that one cannot do as one pleases - systematic laws and regulations constrain us, but do not imply domination - but that one is at risk of having to follow the personal desires and interests of another. "The dominating party can practise interference, then,

\footnotetext{
${ }^{5}$ As Lippert-Rasmussen (2015) argues, it is possible to have a pluralist conception of distributive justice that includes concerns over both the distribution of non-relational goods, and the forms of interpersonal relations. ${ }^{6}$ Pettit (2013) argues that Kant was similarly opposed to domination of one person by another, but drew less egalitarian implications than Rousseau.

${ }^{7}$ In this vein Anderson (1999: 315) describes being dominated as to "live at the mercy of others' wills", while Rawls (2007: 248) referred to "our natural indignation at being subject to the arbitrary power of others (a power that makes us do what they want, and not what we both can will as equals)" (Quoted in O'Neill (2008: 128).
} 
at will and with impunity" (Pettit 1999, p. 22). Since domination refers to the capacity to command, and does not imply that this capacity is in fact being exercised, it is formally a variety of entitlement: the entitlement to command another person.

While entitlements over labor imply the ability to employ and command others, it should be distinguished from exploitation, where exploitation is defined as "the acquisition of economic benefits from the labor of those who are dominated" (Olin Wright 2009: 107). In the case of entitlements over labor, the dominating agent is not acquiring economic benefits, but instead is able to command another to fulfil their personal desires and interests. In fact, this implies that entitlements over labor are a clearer case of domination than is capitalist exploitation. This is because capitalist exploitation, even if it is ultimately directed at producing profits for the capitalist, is not entirely "at the agent's pleasure": under capitalist relations the margin for arbitrary treatment of the worker is constrained by the imperatives of production. A capitalist or manager is required to give orders that are consistent with productive efficiency within the firm, and to the extent that they give orders that go beyond those imperatives, they are not acting as a capitalist or manager. ${ }^{8}$ In contrast, entitlements over labor provide one with genuinely arbitrary rights to command others, in the sense that those commands can follow any whim of the entitled. Unlike work that produces goods and services for an anonymous market, in this case the work done has no end beyond fulfilling the "will" or the "pleasure" of the entitled dominator.

The step from domination to social inequality is straight forward: domination implies "social subordination to others" (Pettit 1999, p. 274; also see Scanlon 2003, pp. 204-205), and "a profound asymmetry in whose interests count" (Anderson 2017, p. 5). It implies "relational inequality", where relational egalitarians conceive of equality as "a kind of social relation

\footnotetext{
${ }^{8}$ Rather, in that case they are taking advantage of their position as capitalist or manager in order to give arbitrary commands.
} 
between persons - an equality of authority, status, or standing” (Anderson 2010, p. 1). The implications of relational inequality were vividly described in Tom Wolfe's (1968) portrayal of the lifestyle of the very wealthy: "It's not even the exercise of power... It's a feeling... knowing that anywhere they go, people will move for them, give way, run errands, gather around... and jump..." [ellipses in original]. Similarly, Palmer (1989: 159) noted that "much of the feeling of greatness (of power) comes from being served". Anderson $(1999,2017)$ further argues that historical egalitarian movements were concerned not with inequality in the distribution of incomes (associated in political theory with luck egalitarianism), but instead opposed social orders based on "a hierarchy of human beings", where "inequality referred not so much to distributions of goods as to relations between superior and inferior persons." (Anderson 1999, p. 312; Anderson 2017, chapter 1).

So far I have argued that entitlements over labor provide a measure of domination, and that domination leads to social inequality and hierarchy. Research on the psychology of marketing also provides suggestive support for the connection between the affordability of labor and social hierarchy: when a given good has a higher price, it is accorded a higher value by the consumer. Rao and Monroe (1989) found that for a range of products, a perceived higher price led consumers to think more highly of the product. Plassman et al. (2008: 1050) found that when consumers believed that a given wine was more expensive, they reported higher subjective "flavour pleasantness", and that functional MRIs showed higher experiential "pleasantness". It therefore seems plausible that when labor is cheaper to the rich, i.e. they have higher entitlements over labor, then the rich will place lower social value on the people who serve them, encouraging the notion that there are "superior and inferior persons" (Anderson 1999: 312).

The above discussion suggests that a reduction in entitlements over labor leads to a decline in domination and social inequality. However, as Pettit notes, domination can be 
avoided either "in virtue of an equal distribution of relevant resources" or "by courtesy of constitutional provision" (p. 69). Entitlements over labor measure the former: the extent to which the distribution of economic resources, or the market, allows or limits domination and social inequality. It does not measure the constitutional provisions, nor indeed the policies, institutions and organizations of the state and of civil society, that affect relations of domination.

Regarding entitlements over labor specifically, the public sector can play an important role in the extent to which these entitlements are in fact exercised. Most obviously, public provision of services can decommodify what might otherwise be purchased in the market. Consider childcare. When this is provided by a privately-employed nanny, her position and her behavior are subject to the whim of the employing parent. When it is provided by a public nursery, on the other hand, parents have no direct command over staff: the user of the service is not receiving it as a result of entitlements over labor, but instead as a result of public policy. ${ }^{9}$ This suggests that public provision of childcare would reduce the extent to which childcare implies the exercise of entitlements over labor, and relations of domination. ${ }^{10}$ A similar point would apply to taxi or rickshaw rides versus public transport - the more public transport is provided, the lower will be the use of entitlements over labor to obtain transport services.

Moreover, the extent of domination in any employment relationship, whether through the exercise of entitlements over labor or in other types of employment, depends on labor rights and bargaining power. At one extreme lies the US, the only country in the OECD that requires

\footnotetext{
${ }^{9}$ This relates to Kröger's (2011) concept of dedomestication, or freedom from reliance on the family for care (whether as the one who is expected to do the caring, or as the one who receives the care). However, while dedomestication could occur through either public or private provision of care services, here the distinction between public and private provision is key.

${ }^{10}$ Both Palmer (1989) and Manning (2004) note that these services are often provided in the private market through an intermediary company, rather than through the direct employment of domestic workers. The extent to which this reduces domination will depend on how much control the paying parents have over staff, which is likely to be higher than in the case of a publicly-provided service, though lower than for a private nanny.
} 
neither notice nor severance pay when firing workers (OECD 2013, p. 78). ${ }^{11}$ In the US, "employees can be fired for good reasons, bad reasons, or no reason at all", and signing an employment contract often implies "the alienation of many of their basic rights (speech, privacy, association, and so on) in exchange for pay and benefits" (Bertram 2012). In other countries, restrictions on firing practices and explicit limitations on the scope of employer behaviour, whether legislated or negotiated by unions, reduce the extent to which employers can dominate their employees (OECD 2013, p. 66). Such protections reduce the likelihood of domination by employers by either outlawing or raising the costs of actions that harm worker interests. Furthermore, regulations that give workers voice in management decisions, such as worker representation on company boards, reduce the likelihood that such actions will be pursued.

Entitlements over labor therefore capture the market-based determinants of domination and social hierarchy, not the social determinants. This implies a parallel between entitlements over labor and standard inequality measures that are based on distributions of disposable income or expenditure: the latter similarly capture only the market-based determinants of economic welfare, and do not count the role played by non-market factors such as the environment, and in-kind benefits such as public health and education services. ${ }^{12}$

While economic entitlements over labor are logically distinct from legal or institutional labor protections, they plausibly have a causal relationship: greater labor rights lead to lower economic inequality and hence lower entitlements over labor. Jaumotte and Buitron (2015) find a strong negative relationship between unionization and top income shares, arguing that this is because unions increase the earnings of low- and middle-income earners at the expense

\footnotetext{
${ }^{11}$ At the federal level; some states provide greater labor protections.

12 The income concept of final income accounts for in-kind benefits, though not environmental factors (see e.g. Lustig, 2018), and estimating it requires additional data and assumptions beyond standard estimates. These inkind benefits can have a large impact: Paulus et al. (2009) find that they reduce the Gini coefficient by between 3.9 and 6.0 percentage points in five European countries, relative to disposable income.
} 
highly-paid managers and share holders. This would likely imply a similar negative correlation between unionization and entitlements over labor of top income groups.

\section{3: Measuring entitlements over labor}

In measuring what I call entitlements over labor, three authors have suggested different approaches. Milanovic (2010) compares the wealth levels of some of the richest individuals in history using per capita GDP as numeraire, interpreting it as the cost of employing a contemporary worker. On this measure he estimates that the richest person in history is Mexico's Carlos Slim, whose income was 440,000 times Mexico's per capita GDP. Atkinson (2007) proposed to measure "command over people" by estimating the share of the population with gross income in excess of ten times average earnings. ${ }^{13}$ Piketty (2014: 348) remarked that in nineteenth century France an individual inheriting in the top 1\% of bequests "could afford to pay a staff of 25-30 domestic servants throughout his life" from his capital income, estimating the cost of a domestic servant as the average income of the bottom $50 \%$ of the population.

The use of per capita GDP as a proxy for wage costs is questionable: Bleynat, Challú and Segal (2017) find that in Mexico the ratio of per worker GDP to urban wages ranged from 0.6 in the nineteenth century to over three in the twenty-first century. Atkinson's average wages is preferable, but it retains the drawback of including the wages of highly skilled professionals. Since the concern here is command over people, not human capital, I use median wages. This follows the Stiglitz Commission's argument that the median is more representative of the "typical" individual (Stiglitz et al, 2009, pp. 13-14). And where Atkinson suggests gross income as the numerator, I use disposable income in order to capture entitlements.

\footnotetext{
${ }^{13}$ Atkinson (2006) applied this approach to wealth, defining the "rich" as those with net wealth greater than 30 times average income.
} 
Thus I measure entitlements over labor of income group $G$ by

$$
E^{G}=\frac{Y^{G}}{w}
$$

where $Y^{G}$ is the mean disposable income of group $G$ and $w$ is the cost of employing a worker on median wage (which may include additional payments such as social security). Moreover, following Piketty, I define entitlements over low-wage labor $E_{L}^{G}=\frac{Y^{G}}{w_{L}}$ where $w_{L}$ is the cost of employing a worker on the average wage of the bottom $50 \%$.

As with all inequality measures, different definitions of the underlying income concepts are possible. Standard inequality measures are applied to a variety of income concepts including consumption expenditure, pre-tax income, and disposable income, any of which may be calculated as per household, per capita, or per equivalized adult, and applied to a variety of population units, including households, individuals, or adults (Anand and Segal 2008). Often the strictly-correct distribution is not available and another is used as an approximation, as in some World Bank estimates of consumption poverty that use income surveys (e.g. Ferreira et al., 2016). Similarly, entitlements over labor could be applied to different income concepts at the top of the distribution and different definitions of 'typical wages', depending on judgement and data availability. For instance, the "Palma ratio", defined as the ratio of the income share of the top $10 \%$ to that of the bottom $40 \%$ (Cobham and Sumner 2013), could be interpreted as an approximation to the entitlements over low-wage labor of the top $10 \%$, where low wages refer to the bottom $40 \%$. 


\section{Estimates of entitlements over labor}

I estimate entitlements over labor of the top $1 \%$ for the two middle-income countries Brazil and Mexico, and the three high-income countries Slovenia, Sweden, and the USA, shown in figure $1 .{ }^{14}$ Brazil, Mexico and the USA are all high-inequality countries while Slovenia and Sweden have low levels of inequality. For comparison, figure 2 shows the Gini coefficients of the same countries. The ordering of the five countries remains the same across the two inequality measures. Above we saw that the degree of domination and social inequality in a society are likely to be influenced by labor rights in addition to entitlements over labor. Consistent with this, all three of the high-inequality countries have low employment protection while both of the low-inequality countries have high employment protection: according to the OECD,${ }^{15}$ the USA has the lowest employment protection among the 46 countries for which they collect data, while Brazil is in the second decile from the bottom; Mexico is at the median on this measure, but on the other hand more than half of the population is employed informally, meaning they do not enjoy those legal protections (ILO 2012). Sweden and Slovenia, in contrast, are in the eighth decile for employment protection. Table 1 indicates the relative positions of the countries in their levels of income, inequality and labor rights.

\footnotetext{
${ }^{14}$ For the USA, Sweden and Slovenia I add employers' social security contributions and payroll taxes to the cost of wages, as reported by the consultancy firm KPMG, downloaded 26 October 2017 from https://home.kpmg.com/xx/en/home/services/tax/tax-tools-and-resources/tax-rates-online/social-securityemployer-tax-rates-table.html. For Brazil and Mexico I assume these are zero because of the high degree of informality in the labor market.

${ }^{15}$ OECD.Stat, Strictness of employment protection - individual and collective dismissals (regular contracts) [https://stats.oecd.org/Index.aspx?DataSetCode=EPL OV]. Data are for 2012, the latest year in which all five countries have estimates.
} 
Figure 1: Top 1\% entitlements over labor in five countries

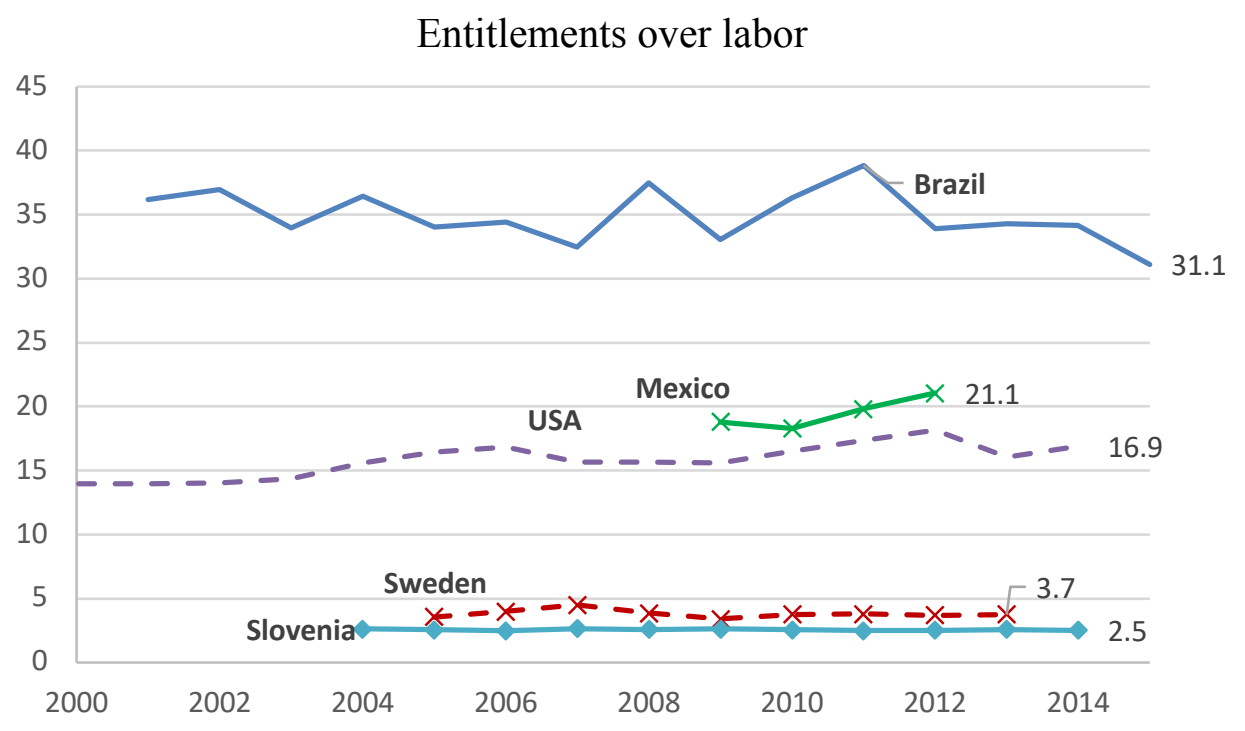

Entitlements over low-wage labor

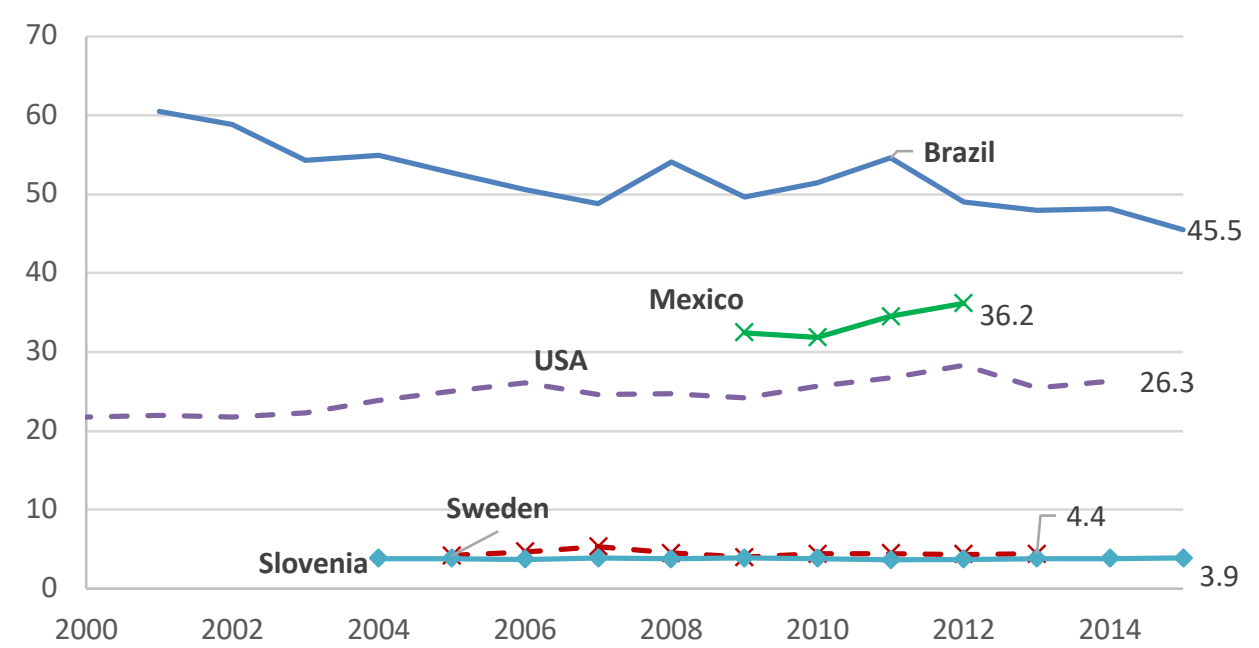

Sources: Author's calculations. See Appendix for data sources. Note: Entitlements over labor give the ratio of disposable incomes of the stated income group to the cost of employing a worker on median wage. Entitlements over low wage labor give the ratio of those disposable incomes to the average cost of employing a worker in the bottom $50 \%$ of the wage distribution. 
Figure 2: Gini coefficients in five countries

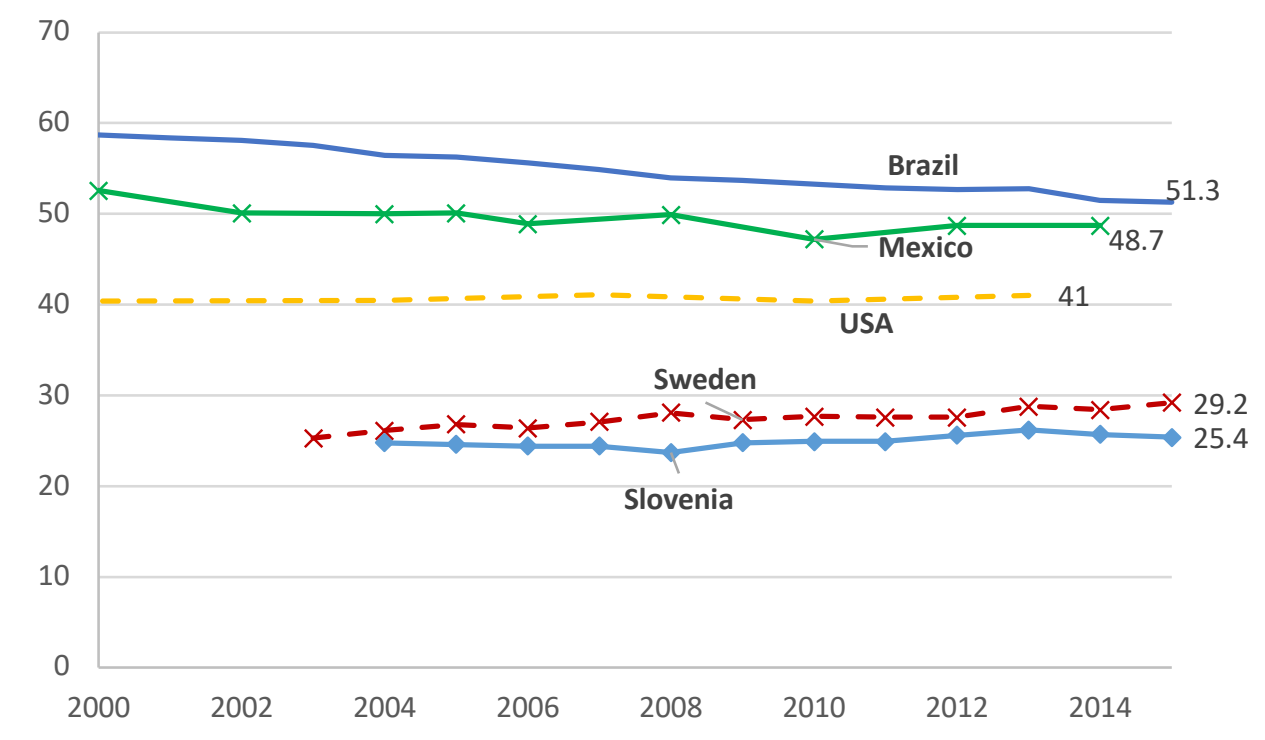

Source: World Bank, World Development Indicators,

[https://databank.worldbank.org/reports.aspx?source=world-development-indicators],

downloaded 19/12/2019.

Table 1: Income, inequality and labor rights in four countries

\begin{tabular}{|l|l|l|l|}
\hline & Income & Inequality & Labor rights \\
\hline Brazil & Middle & High & $\begin{array}{l}\text { Low, with high } \\
\text { informality }\end{array}$ \\
\hline Mexico & Middle & High & $\begin{array}{l}\text { Medium, with high } \\
\text { informality }\end{array}$ \\
\hline Slovenia & High & Low & High \\
\hline Sweden & High & Low & High \\
\hline USA & High & High & Low \\
\hline
\end{tabular}


One striking difference between the Gini coefficient and entitlements over labor is that the spread of entitlements over labor is much wider. ${ }^{16}$ Comparing the extreme cases, Brazil's Gini is twice as high as Slovenia's, while its entitlements over labor are 12 times higher, at 31.1 compared with 2.5 in the latest years. By construction, the Gini is bounded between zero and one. Entitlements over labor, on the other hand, are not bounded. It is plausible that this higher ratio better communicates the comparison between one of the most unequal countries in the world and one of the most equal. More importantly, the interpretation and the normative significance of these radically different levels of entitlements over labor is transparent, in contrast to the dubious normative interpretation of the Gini. ${ }^{17}$

It is also illuminating to consider entitlements over labor in terms of the affordability of labor for the rich. Consider the two richest countries, Sweden and the US, whose real per capita GDPs are similar: entitlements over labor for the top 1\% were 3.7 in Sweden and 17 in the US, meaning that the average person in the top $1 \%$ in Sweden would have to spend $27 \%$ of their disposable income to employ a median worker full time, in contrast to just $6 \%$ in the US. In the most equal country, Slovenia, someone in the top $1 \%$ would have to spend fully $40 \%$ of their disposable income to employ someone on median wage. In the highly unequal middleincome countries Brazil and Mexico, someone in the top 1\% would need to spend respectively only $3.2 \%$ or $4.7 \%$ of their income to employ a median-wage worker, falling below $3 \%$ for a low-wage worker. Comparing across income groups, the top $10 \%$ in the US has entitlements over labor of 4.1, higher than the top $1 \%$ in Sweden, implying that labor is more affordable to

\footnotetext{
${ }^{16}$ The fact that the ordering of countries is the same is to be expected as they are all measures of economic inequality broadly conceived. For comparison, across the Luxembourg Income Study's 364 country-year observations, the Gini coefficient has a rank correlation coefficient of 0.97 with the Atkinson coefficient $(\varepsilon=1)$ and 0.93 with the 90/10 percentile ratio (calculated using LIS 2019).

${ }^{17}$ Atkinson (1970) shows that the Gini implies that the impact on social welfare of a transfer between person A and person B depends on the share of individuals with incomes in between their respective income levels, and is independent of either the absolute or relative incomes of A and B. This is a statistical artefact with no normative justification. Also see Sen (1973) for discussion.
} 
the average person in the top decile in the US, than to the average person in the top $1 \%$ in Sweden.

We can also consider entitlements over labor as a measure of real income, following Adam Smith and, more recently, Milanovic (2010). ${ }^{18}$ In the latest year the top $1 \%$ in Sweden had disposable incomes of PPP\$178,000, making them substantially richer in terms of overall consumption goods and services than their counterparts in Mexico, who had PPP\$107,000. But those in Mexico could afford to command the labor of 21 full time workers, compared with 3.7 in Sweden.

How do entitlements over labor compare with top income shares? To examine this question we consider the case of the USA in more detail. Income shares of top income groups have grown substantially in recent years (Piketty et al., 2017). Figure 3 and table 2 indicate that their entitlements over labor grew faster still. While the income share of the top $1 \%$ grew by

Table 2: Entitlements over labor and income shares in the USA, 1990-2014

\begin{tabular}{llllllllll} 
& Top & Top 1\% & Top & Top 5\% & Top 5\% & Top & Top & Top & Top \\
& $1 \% \mathrm{E}$ & E(low & $1 \%$ & $\mathrm{E}$ & $\mathrm{E}($ low & $5 \%$ & $10 \% \mathrm{E}$ & $10 \%$ & $10 \%$ \\
& & wage) & share & & wage) & share & & E(low & share \\
& & & $(\%)$ & & & $(\%)$ & & wage) & $(\%)$ \\
\hline 1990 & 10.4 & 16.4 & 12.5 & 4.2 & 6.6 & 25.0 & 2.9 & 4.5 & 34.5 \\
2000 & 14.0 & 21.8 & 14.4 & 5.4 & 8.4 & 27.8 & 3.6 & 5.7 & 37.7 \\
2010 & 16.5 & 25.7 & 17.3 & 5.8 & 9.1 & 30.5 & 3.9 & 6.0 & 40.2 \\
2014 & 16.9 & 26.3 & 17.1 & 6.1 & 9.5 & 30.9 & 4.1 & 6.3 & 41.0 \\
Growth & & & & & & & & & \\
$1990-$ & & & 36.2 & & & 23.9 & & & \\
2014 & $62.5 \%$ & $60.2 \%$ & $\%$ & $47.7 \%$ & $45.6 \%$ & $\%$ & $41.3 \%$ & $39.3 \%$ & $18.7 \%$
\end{tabular}

Source: see figure 1.

\footnotetext{
18 To the extent that the price of non-tradables depends on labor costs, entitlements over labor may be interpreted as a measure of real income in terms of non-tradables. This mirrors the fact that incomes at market exchange rates can be interpreted as real income in terms of tradables (Anand and Segal 2008: 70ff). Then PPPbased income comparisons, which account for the prices of all goods and services, can be seen as a balance between the two.
} 
Figure 3: Entitlements over labor and income shares in the USA, 1990-2014
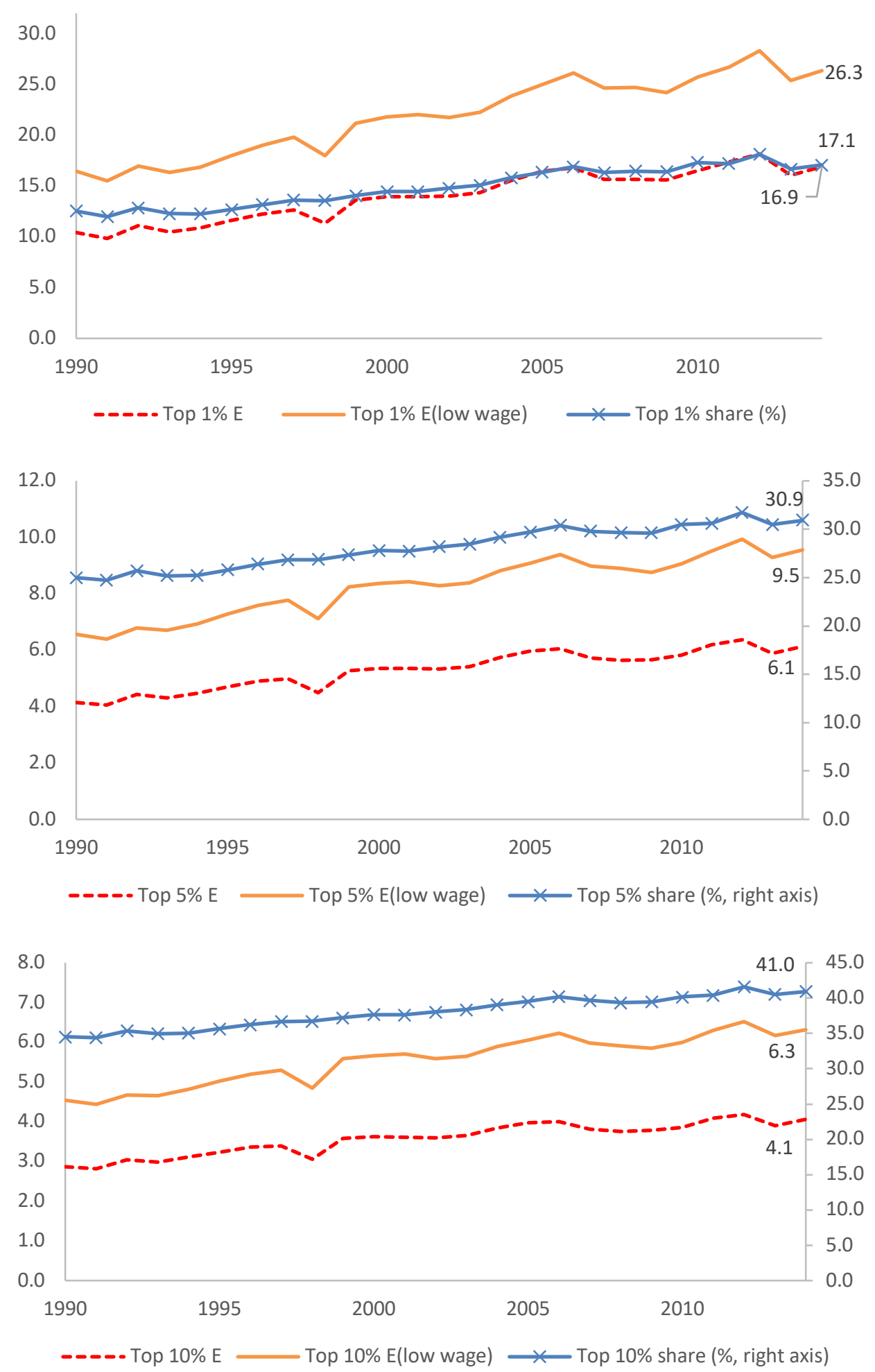

Sources: Author's calculations. See Appendix for data sources. Note: E is entitlements over labor, giving the ratio of disposable incomes of the stated income group to the cost of employing a worker on median wage. E (low wage) give the ratio of those disposable incomes to the average cost of employing a worker in the bottom $50 \%$ of the wage distribution. 
$36 \%$ over $1990-2014$, their entitlements over labor, and over low-wage labor, grew $63 \%$ and $60 \%$ respectively. Similarly, entitlements over labor of the top 5\% grew 46 to 48 percent while their income share grew 24 percent. The difference between income shares and entitlements over labor is in the denominator: for shares, the incomes of the rich are divided by average income; for entitlements, the incomes of the rich are divided by median or bottom- $50 \%$ wage costs. Entitlements grew faster than shares because both the median wage and bottom-50\% wages grew more slowly than average incomes: in nominal terms the median wage grew $80.2 \%$ and bottom $50 \%$ wages grew $82.8 \%$, while mean income grew $115.1 \%$. (For comparison, CPI inflation was $81.2 \%$ over the period.) Thus this aspect of the rise in inequality is captured by entitlements, but not by shares. The rapid rise in top income shares in the USA in recent decades has been widely discussed and presented as salient to both national wellbeing and national politics. The ability of the rich to command poorer people for their own enjoyment has grown more even rapidly.

\section{The social and political salience of entitlements over labor}

I have argued that entitlements over labor provide an empirical measure of republican and relational conceptions of equality. I now argue that this approach is also of practical relevance. On a micro level, empirical studies find that social inequality and hierarchies are salient for human well being. In the psychology literature, Boyce (2004) finds that children who are low in a social dominance hierarchy tend to suffer worse morbidity and mental health symptoms, while Zink et al. (2008) find that social hierarchical rewards to performance are of comparable salience to monetary rewards, using functional MRIs. The economic literature finds that those with high social status are likely to be treated more favourably by others, both in terms of market goods and in terms of social treatment (Weiss and Fershtman 1998, Heffetz and Frank 2010). These all support Ridgeway's (2014, p. 2) observation that "people care about 
status quite as intensely as they do money and power." Beyond these micro level empirical findings, I now argue that that entitlements over labor also have macro-level social and political salience.

\section{Entitlements over labor and the "middle class"}

Entitlements over labor matter socially because in many countries they are central to popular conceptions of affluent and "middle class" lifestyles. The link is via domestic service, the most direct instantiation of entitlements over labor. Veblen (1899: 59) famously remarked that domestic servants are "useful as a method of imputing pecuniary respectability to the master or to the household." In this vein Palmer's (1989: p. x) study of domestic service in the USA reported that "the independent women of my family had felt they must have domestic labor in order to achieve genteel propriety".

Moreover, domestic service provides not just respectability but also an essential service to well-off households in high-inequality countries. Qualitative evidence suggests this is the case in all three high-inequality countries examined above. Reporting from São Paolo, Rapoza (2013) remarked: "Ask an expat [from a rich country] what they love most about living overseas and they will inevitably tell you this: the taxes and the maid service. That's right. Maids.” O’Dougherty (2002: 209) notes that typical two- or three-bedroom upper-middle class homes in São Paolo include a "service (i.e. maid's) area", and her documentation of the lives of these households contain repeated references to domestic servants. In Mexico the indispensability of domestic workers is indicated by the fact that they are often referred to as la felicidad de la casa, or "the happiness of the household" (e.g. de la Torre, 2014; Mexia, 2013). In this vein, Brooks (2020) suggests that in the US the affordability of nannies, tutors, therapists and other household help to the affluent helps explain why richer families are more stable than poorer families, while Palmer (1989: x) reported that, as a "middle class" 
professional in Washington, D.C., "Nearly all of my women friends in Washington hire another woman to do some of 'our' work".

We find similar attitudes in high-inequality China and India. Sun (2009, pp. 10-16) describes maids as "indispensable to the smooth running of the household" for the "emerging urban middle class" in Beijing. In Delhi, Lahiri (2012) reported that "one of the widely acknowledged perks of living here - the one many Indians abroad think of most wistfully" is "the availability of cheap household help." This recalls the finding above that the top $1 \%$ in Mexico cannot afford all the goods and services available to their Swedish counterparts, but they can afford to command more labor: for high-skill professionals from emerging economies, moving to a richer and less unequal country probably increases overall consumption opportunities, while reducing the affordability of domestic service.

Indeed, in Sweden, where we saw that elite entitlements over labor were low, the social norms are quite different: in the "Swedish maid debate" of the 1990s, a proposed tax break for working couples employing domestic workers was publicly denounced as implying "a return to the depraved and obsolete days of servants" (Bowman and Cole 2009: 161). Sweden's large public sector, which provides heavy public subsidies to childcare, implies a strong degree of decommodification of personal services. Where labor is expensive even for upper income groups, and many services are provided by the public sector, it seems plausible that social norms adapt: the acquisition of personal services through the exercise of entitlements over labor seems retrograde in this society.

Most rich countries, however, have not resisted the return to the days of servants, and have experienced a rise in employment in occupations that "involve assisting or caring for others" (Autor and Dorn 2013: 1555). This rise in service appears to have been driven by two factors. First, technical change has tended to substitute for routine tasks that, in the past, were performed by low-skilled labor, pushing up the supply of workers for low-skill service 
occupations that cannot be mechanized. Second, in the US case, the demand for "home production substitutes" by the highly-paid has increased as inequality has increased, because rising inequality means the opportunity cost of their time rises relative to the cost of these services (Milkman et al 1998; Manning 2004; Mazzolari and Ragusa 2013). ${ }^{19}$ What these studies refer to as the opportunity cost of the time of the rich relative to the cost of labor for home production substitutes is effectively what we measure with entitlements over labor.

It should be stressed that domestic service per se is neither necessary nor sufficient to create domination and social hierarchy. It is consistent with social equality that I clean your house and you look after my children. The social hierarchy arises when reciprocity breaks down because person A can purchase the services of person B, and not vice versa - which is precisely when entitlements over labor are high. Rollins (1985) highlights this social hierarchy when she describes the mistress-servant relationship in the USA as "an extreme and 'pure' example of a relationship of domination in close quarters" (pp. 8-9) and reports that in her interviews with domestic servants, "all domestics concurred that employers appreciated some forms of deference and outward signs of subservience" (p. 147).

\section{The political economy of entitlements over labor}

The importance of domestic service to the upper middle classes means that its affordability can also have implications for political economy. The "social conflict view" of political economy (Acemoglu, Johnson and Robinson, 2005) explains political outcomes on the basis of conflicts of interest between groups. Marxist analyses of social conflict focus on the conflict between owners of capital and their employees over the level of wages, where wages are income for workers, and an input cost for capitalists. More recently, Acemoglu and Robinson (2009, chapter 8) represent the conflict of interest as a conflict over redistributive

\footnotetext{
${ }^{19}$ However, Goos, Manning and Salomons (2009) find this does not apply across European countries.
} 
taxation. Inequality as entitlements over labor represents a third locus of conflict that has not been studied in the political economy literature: typical wages represent income for the majority, but a consumption price for the rich and upper middle classes. This implies a direct conflict of interest between wage earners on the one hand, and the rich and upper middle classes who enjoy labor entitlements on the other hand.

Conflict over entitlements over labor is likely to be particularly intractable for the following reason. When conflict is over the distribution of goods and services in general, economic growth relaxes the resource constraint and can allow all classes to increase their real incomes, attenuating conflict. But this possibility is much more limited for command over labor. As first shown by Baumol (1967: 415-16), productivity improvements are necessarily limited in sectors where "labor is an end in itself". This point applies to what Acemoglu and Autor (2011: 1077) describe as non-routine manual tasks, i.e. "activities that require situational adaptability, visual and language recognition, and in-person interactions," which include domestic and personal services such as care work, cleaning, and chauffeuring. If the rich want personal service, they cannot achieve it through technological progress: they need to keep their incomes high relative to the wages of the non-rich. In the sense of entitlements over labor, inequality per se benefits the rich. ${ }^{20}$

We can observe this form of conflict in the recent political history of Brazil, and the downfall of the Workers' Party (PT) government. The PT's Dilma Rousseff became President in 2011 and won a second term starting in 2015, but was impeached in 2016 after allegations of corruption. While the so-called lavajato investigation uncovered high levels of corruption throughout Brazil's political class, Dilma was never found to have been involved in the corruption herself, and the legality of her impeachment was debatable (Saad-Filho 2016). What

\footnotetext{
${ }^{20}$ Consistent with this, Bertram (2015) argues that a desire to command labor, or dominate the lower classes, may lead higher income groups to "favour policies that enhance the subordination of the least advantaged and make those people disposed to act according to the bidding of the wealthy".
} 
was certain was that she had lost the support of a large share of the upper middle class, who joined anti-government demonstrations around the country on 13 March 2015 and then again in June (Flynn and Soto 2016, Saad-Filho 2016). While a cross-section of society participated in these demonstrations, they were disproportionately highly educated (Singer 2014). Amid a major recession, there was widespread agreement that "the upper-middle class felt squeezed economically" (Saad-Filho 2016; also see Braga 2016).

Does this "squeeze" show up in the data? Consider the p91-99 group, defined as the top decile excluding the top $1 \%$, which is a plausible interpretation of this upper-middle class. Table 3 shows that neither their real incomes nor their income share declined significantly under Dilma: both were virtually unchanged over her presidency, 2011-2015. Thus there was no "squeeze" on the upper middle class in terms of absolute or relative purchasing power over a representative basket of goods and services. However, where they did lose purchasing power was over labor, owing to the rise in wages in the bottom and middle of the distribution: table 3 shows that their entitlements over median-wage labor fell $14 \%$ while entitlements over lowwage labor fell 11\%. If we consider the period under PT rule from 2003, started by President Lula da Silva and continued by Dilma, the p91-p99 group saw their real incomes rise by $29 \%$ and their income share virtually unchanged, but their entitlements over median-wage and lowwage labor fall by $11 \%$ and $22 \%$ respectively. ${ }^{21}$

We saw above the importance of domestic service to the upper middle class in Brazil, a country where domestic workers comprise 7.8 percent of all workers (ILO 2013, p. 124). For these households, rising wages represented rising costs of essential services. This broader wage trend was exacerbated for domestic labor by a 2013 constitutional amendment that increased domestic workers' rights, including a prohibition on wage deductions for lodging and meals

\footnotetext{
${ }^{21}$ The combination of stable income shares at the top and falling entitlements over labor is explained by the fact that there was a decline in inequality within the bottom $90 \%$ of the population.
} 
(ILO 2013, p 81). Numerous media reported growing upper-middle class anxiety over the rising cost of domestic service. For Bloomberg.com, Goodman (2013) reported that the constitutional amendment was "spreading concern among middle and upper-class families that the cost of employing a maid or nanny will spike". Rapoza (2013) remarked that "Brazilian maid service is becoming professionalized, and that has pulled the rug out from the middle class that has come to depend on them to keep their house in order." Moreover, consistent with our earlier discussion of social status and hierarchy, the rise of service and other low-skill wages reduced the social distance between the poor and the rich, to the displeasure of the latter: Braga (2016) comments that "workers 'invaded' spaces previously reserved for the traditional middle classes, such as shopping malls and airports”. In 2020, President Bolsonaro's Minister of the Economy, Paulo Guedes, justified a devaluation of the currency by remarking that during the PT government, "even domestic workers went to Disney... it was a terrible party". ${ }^{22}$

Table 3: Entitlements over labor and income shares in Brazil, 2001-2015

\begin{tabular}{|c|c|c|c|c|}
\hline & $\begin{array}{l}\text { p91-99 } \\
\text { share }\end{array}$ & $\begin{array}{l}\text { p91-99 real } \\
\text { income, } \\
2010 \mathrm{R} \$\end{array}$ & $\begin{array}{l}\text { p91-p99 } \\
\text { E(median) }\end{array}$ & $\begin{array}{l}\text { p91-p99 } \\
\text { E(bottom50) }\end{array}$ \\
\hline 2001 & 29.9 & 48,414 & 5.1 & 8.5 \\
\hline 2011 & 29.6 & 62,133 & 5.2 & 7.4 \\
\hline 2015 & 29.7 & 62,587 & 4.5 & 6.6 \\
\hline & $-1 \%$ & $29 \%$ & $-11 \%$ & $-22 \%$ \\
\hline & $0 \%$ & $1 \%$ & $-14 \%$ & $-11 \%$ \\
\hline
\end{tabular}

Source: Author's calculations, and see Appendix. Note: p91-99 is the top decile, less the top $1 \%$.

\footnotetext{
${ }^{22}$ Pagina 12, "La frase despectiva del ministro de Economía de Brasil: 'Hasta las empleadas domésticas iban a Disney", https://www.pagina12.com.ar/247411-la-frase-despectiva-del-ministro-de-economia-de-brasil-hasta, 14 February 2020.
} 
Singer (2014) suggests that for the upper middle classes in Brazil, politics has moved towards "post-materialism" by focusing on quality of life rather than income. A problem with this argument is that while upper middle class quality of life may not depend on consuming ever-more goods, it does depend a great deal on the affordability of other people's labor. That depends not on real income as usually measured, nor even on income shares, but specifically on entitlements over labor. By measuring the capacity to command others, and the social hierarchy that flows from that capacity, entitlements over labor capture a socially- and politically-salient aspect of inequality that standard measures do not.

\section{Concluding remarks}

Research on economic inequality has enjoyed huge growth in recent years and a multitude of studies have increased our knowledge of income distributions around the world. But there has been no corresponding rise in attention to the normative basis for measuring inequality. The traditional welfarist approach is a powerful justification, but it remains a narrow normative base compared with the range of egalitarian motivations that have driven social movements and political thinkers. I have argued that entitlements over labor provide an empirical measure that captures concerns over domination and republican freedom, and relational and social inequality. These concerns have motivated historical egalitarian movements, and they remain highly salient today. The ability to command others for their personal gratification is of great importance to the affluent and upper middle classes, who rely on domestic service and enjoy their superior position in the social hierarchy. At the same time, those lower down the distribution suffer domination, and an inferior social standing that can lead to physical and mental health problems. Unlike competition over goods and services, whose total quantity will rise with economic growth, this is a zero sum game. 
Entitlements over labor range from over 30 for the top 1\% in Brazil to 17 in the USA and as low as 3.7 in Sweden and 2.5 Slovenia, suggesting very different social relations in these countries. Where upper income groups enjoy high entitlements over labor, qualitative evidence suggests that domestic service becomes normalized and considered an indispensable service to those households. Brazil is a case of extreme economic inequality and social hierarchy, and I argued that upper middle class fear of the rising wages of domestic workers, measured by declining entitlements over labor and confirmed by qualitative reports, contributed to their withdrawal of support from the PT government. In contrast, in egalitarian Sweden, where such labor is unaffordable even for the relatively rich and where public provision has decommodified some of these services, many perceive domestic service as retrograde.

While this paper has explored some of the implications of entitlements over labor, it can provide a new perspective on a range of social phenomena beyond those analysed here. Entitlements over labor also provide a mechanism linking status inequality and categorical inequalities: when types such as ethnic minorities, women, and immigrants become associated with the subordinate role of serving higher-status types, those types themselves become associated with low social status (see Massey 2007). This often has a strong international dimension through global care chains (Hochschild 2015), as domestic workers migrate from poorer countries to richer countries, reproducing inequalities between countries within the home. Moreover, associations between category and subordinate labor can become selfreinforcing through Tilly's (1998) process of 'emulation', whereby observed categorical divisions of labor become replicated. In the case of Brazil, for instance, domestic workers are disproportionately Black women, and their role in raising children of the upper middle classes allows those children to be "socialized in a deeply hierarchical logic, which places the maids in a world apart" (Brites 2016, p. 103). 
At the same time, women are not only at the service end of the relationship, but can also be the ones enjoying entitlements over the labor of others. Palmer (1989) confirmed the dependence of "middle class" professional women in Washington, D.C., on paid domestic workers. A personal profile on the US academic economist couple Betsey Stevenson and Justin Wolfers, both full-time professionals working on the economics of the family and life satisfaction, reported that they employed a nanny for 55 hours a week to look after their only child, in addition to "someone who drives them back and forth to Princeton and who cooks, does the laundry and snakes the drains when they are clogged" (Rich 2012). Given the prevalence of gender norms that place the responsibility for domestic work on women, a woman's decision on whether to enter the workforce will typically depend on the opportunity cost of her time relative to the price of domestic labor - i.e., her entitlements over labor.

These and other social phenomena that shape our lives depend on or express some variety of inequality. Yet our understanding of how to measure these inequalities, and how to understand the linkages between them, lags behind the remarkable growth in both data on inequality and interest in the topic. The theory of inequality as entitlements over labor is a step towards a fuller understanding of what we care about when we care about inequality. 


\section{References}

Acemoglu, Daron and James A Robinson (2009), Economic Origins of Dictatorship and Democracy, Cambridge University Press.

Acemoglu, Daron, James A Robinson, and Simon Johnson (2005), "Institutions as a Fundamental Cause of Long-Run Growth", in Philippe Aghion and Steven N. Durlauf (eds.), Handbook of Economic Growth, Volume 1A, North Holland, pp. 386-472.

Acemoglu, Daron and David Autor (2011), "Skills, Tasks and Technologies: Implications for Employment and Earnings", Handbook of Labor Economics, Volume 4B, North Holland, pp. 1043-1171.

Anand, Sudhir and Paul Segal (2008), "What Do We Know about Global Income Inequality?", Journal of Economic Literature, Vol. 46(11), 57-94.

Anderson, Elizabeth (1999), "What Is the Point of Equality?" Ethics 109 (2): 287-337. doi:10.1086/233897.

Anderson, Elizabeth (2010), “The Fundamental Disagreement between Luck Egalitarians and Relational Egalitarians", Canadian Journal of Philosophy 36: 1-23.

Anderson, Elizabeth (2017), Private Government: How Employers Rule Our Lives (and Why We Don't Talk about It), Princeton and Oxford: Princeton University Press.

Atkinson, A. B. (1970), “On the Measurement of Inequality”, Journal of Economic Theory, Vol. 2, No. 3, 244-263.

Atkinson, A. B. (2006), “Concentration among the Rich”, UNU-WIDER Research Paper No. $2006 / 151$

Atkinson, A. B. (2007), "Measuring Top Incomes: Methodological Issues", in Atkinson and Piketty (2007), Top Incomes over the Twentieth Century: A Contrast Between European and English-Speaking Countries, Oxford: Oxford University Press, pp. 18-42. 
Atkinson, A. B. and Francois Bourguignon (2000), "Income distribution and economics", in

A. B. Atkinson and F. Bourguignon (Eds.), Handbook of Income Distribution, vol. 1. Amsterdam: Elsevier.

Atkinson, A. B. and Thomas Piketty (2007) (eds.), Top Incomes over the Twentieth Century: A Contrast Between European and English-Speaking Countries, Oxford: Oxford University Press.

Atkinson, A. B. and Thomas Piketty (eds.) (2010), Top Incomes: A Global Perspective. Oxford: Oxford University Press.

Autor, David H. and David Dorn (2013), "The Growth of Low-Skill Service Jobs and the Polarization of the US Labor Market", American Economic Review, Vol 2013, No. 5, pp. $1553-1597$

Baumol, William J. (1967). 'Macroeconomics of Unbalanced Growth: The Anatomy of Urban Crisis,' American Economic Review 57: 415-26.

Bertram, Christopher (2012), "Let It Bleed: Libertarianism and the Workplace”, ", blogpost, December $\quad 9, \quad$ http://crookedtimber.org/2012/07/01/let-it-bleed-libertarianism-and-the$\underline{\text { workplace/ }}$

Bertram, Christopher (2015), "Piketty, Rousseau and the desire for inequality", blogpost, December 9 ,

http://crookedtimber.org/2015/12/09/piketty-rousseau-and-the-desire-for-inequality/

Bleynat, Ingrid, Amilcar Challú and Paul Segal (2017), "Inequality, Living Standards and Growth: Two Centuries of Economic Development in Mexico”, Department of International Development Working Paper 2017-02, King’s College London.

Bowman, John R. and Alyson M. Cole (2009), “Do Working Mothers Oppress Other Women? The Swedish 'Maid Debate' and the Welfare State Politics of Gender Equality”, Signs, Vol. 35, No. 1, pp. 157-184. 
Boyce, W. T. (2004), "Social stratification, health, and violence in the very young", Annals of the New York Academy of Sciences, Vol. 1036, pp. 47-68.

Brites, Jurema (2016), “Afeto e desigualdade: gênero, geração e classe entre empregadas domésticas e seus empregadores", Cadernos Pagu, (29), pp. 91-109. Retrieved from https://periodicos.sbu.unicamp.br/ojs/index.php/cadpagu/article/view/8644819

Brooks, David (2020), "The Nuclear Family Was a Mistake", The Atlantic, March 2020, https:/www.theatlantic.com/magazine/archive/2020/03/the-nuclear-family-was-amistake/605536/.

Cobham, Alex and Andy Sumner (2013), "Is It All About the Tails? The Palma Measure of Income Inequality”, Center for Global Development, Working Paper 343.

Cowell, Frank A. and Emmanuel Flachaire (2015), "Statistical Methods for Distributional Analysis", in Anthony B. Atkinson and Francois Bourguignon (eds.), Handbook of Income Distribution, Volume 2, 2015, pp. 359-465.

Dalton, Hugh (1920), "The Measurement of the Inequality of Incomes", The Economic Journal, Vol. 30, No. 119, pp. 348-361.

Deaton, Angus, and John Muellbauer (1980), Economics and consumer behavior, New York: Cambridge University Press.

Deaton, Angus (1998), “Getting Prices Right: What Should Be Done?”, Journal of Economic Perspectives, Vol. 12, No. 1, pp. 37-46.

Deaton, Angus (2019), “Inequality in America has lessons for Britain”, FT.com, 14 May 2019, https://www.ft.com/content/4bb86682-756c-11e9-b0ec-

$\underline{7 \mathrm{dff} 87 \mathrm{~b} 9 \mathrm{a} 4 \mathrm{a} 2 \text { ?emailId }=5 \mathrm{cda} 53 \mathrm{e} 326053100044 \mathrm{e} 06 \mathrm{cc} \& \text { segmentId }=7 \mathrm{~d} 033110-\mathrm{c} 776-45 \mathrm{bf}-}$ e9f2-7c3a03d2dd26 
De la Torre, Ferndanda (2014), "Mucho trabajo y mal pagado para la felicidad del hogar", Milenio, March 30, http://www.milenio.com/firmas/fernanda_de_la_torre/trabajo-malpagado-felicidad-hogar_18_271952815.html

Ferreira, Francisco H. G., Shaohua Chen, Andrew Dabalen, Yuri Dikhanov, Nada Hamadeh, Dean Jolliffe, Ambar Narayan, Espen Beer Prydz, Ana Revenga, Prem Sangraula, Umar Serajuddin and Nobuo Yoshida (2016), “A global count of the extreme poor in 2012: data issues, methodology and initial results" Journal of Economic Inequality, 14, pp. 141-172.

Flood, Sarah, Miriam King, Renae Rodgers, Steven Ruggles, and J. Robert Warren (2018), Integrated Public Use Microdata Series, Current Population Survey: Version 6.0 [dataset], Minneapolis, MN: IPUMS, https://doi.org/10.18128/D030.V6.0

Flynn, Daniel and Alonso Soto (2016), "Record Brazil protests put Rousseff's future in doubt", World News, Reuters, https://www.reuters.com/article/us-brazil-rousseff-protestsidUSKCNOWFOIX

Goos, Maarten, Alan Manning, and Anna Salomons (2009), "Job Polarization in Europe", American Economic Review: Papers \& Proceedings, Vol. 99 No. 2, pp. 58-63.

Heffetz, Ori and Robert H. Frank (2010), "Preferences for Status: Evidence and Economic Implications", in Jess Benhabib, Alberto Bisin and Matthew Jackson (eds.), Handbook of Social Economics, Volume 1A, North Holland, pp. 69-91.

Hochschild, Arlie Russell (2015), "Global Care Chains and Emotional Surplus Value", in Engster, Daniel and Tamara Metz (eds.), Justice, Politics, and the Family, New York: Routledge.

ILO (2012), "Statistical update on employment in the informal economy", International Labor Organisation, Department of Statistics, June 2012.

ILO (2013), "Domestic workers across the world: Global and regional statistics and the extent of legal protection", International Labor Office, Geneva. 
ILO; OECD (2015), The labor share in G20 economies, Report prepared for the G20 Employment Working Group.

Jaumotte, Florence and Carolina Osorio Buitron (2015), "Inequality and Labor Market Institutions”, IMF Discussion Note SDN/15/14.

KPMG (2017), "Employer social security taxes", website, https:/home.kpmg.com/xx/en/home/services/tax/tax-tools-and-resources/tax-ratesonline/social-security-employer-tax-rates-table.html

Kröger, Teppo (2011), “Defamilisation, dedomestication and care policy: Comparing childcare service provisions of welfare states", International Journal of Sociology and Social Policy, Vol. 31 No. 7/8, pp. 424-440.

Lippert-Rasmussen, Kasper (2015), "Luck egalitarians versus relational egalitarians: on the prospects of a pluralist account of egalitarian justice", Canadian Journal of Philosophy, 45:2, 220-241, DOI: 10.1080/00455091.2015.1061369

Lustig, Nora (ed.) (2018), Commitment to Equity Handbook: Estimating the Impact of Fiscal Policy on Inequality and Poverty, CEQ Institute at Tulane University, Washington, D.C.: Brookings Institution Press.

Manning, Alan (2004), "We Can Work It Out: The Impact of Technological Change on the Demand for Low-Skill Workers", Scottish Journal of Political Economy, 51(5): 581-608. Massey, Douglas S. (2007), Categorically Unequal: The American Stratification System, New York: Russell Sage Foundation.

Mazzolari, Francesca and Giuseppe Ragusa (2013), "Spillovers from High-Skill Consumption to Low-Skill Labor Markets”, The Review of Economics and Statistics, Vol. 95, No. 1, pp. $74-86$. 
Mexia, Marcela (2013), "El Amor en Tiempos de Google: 5 Tips para Mamá”, blog post, February 22, http://www.marcelamexia.com/el-amor-en-tiempos-de-google-5-tips-paramama/

Moretti, Enrico (2015), "Real Wage Inequality", American Economic Journal: Applied Economics, 5(1): 65-103 http://dx.doi.org/10.1257/app.5.1.65 Real Wage Inequality $\dagger$ By Milanovic, Branko (2010), The Haves and the Have-Nots: A Brief and Idiosyncratic History of Global Inequality, New York: Basic Books.

Milkman, Ruth, Ellen Reese and Benita Roth (1998), “The Macrosociology of Paid Domestic Labor", Work and Occupations, Vol. 25, No. 4, pp. 483-510.

Neuhoser, Frederick (2013), “Rousseau's Critique of Economic Inequality”, Philosophy \& Public Affairs, Vo 41, No. 3, pp. 193-225.

O’Dougherty, Maureen (2002), Consumption Intensified: The Politics of Middle-Class Daily Life in Brazil, Duke University Press.

OECD (2013), Employment Outlook 2013: Protecting jobs, enhancing flexibility: A new look at employment protection legislation, https://dx.doi.org/10.1787/empl_outlook-2013-6-en

Olin Wright, Erik (2009), “Understanding Class: Towards an Integrated Analytical Approach”, New Left Review, 60, pp. 101-116.

O’Neill, Martin (2008), “What Should Egalitarians Believe?”, Philosophy \& Public Affairs, Vol. 36, No. 2, pp. 119-156.

Palma, José Gabriel (2011), "Homogeneous middles vs. Heterogeneous tails, and the end of the 'Inverted-U': the share of the rich is what it's all about", Cambridge Working Papers in Economics (CWPE) 1111.

Palmer, Phyllis (1989), Domesticity and Dirt: Housewives and Domestic Servants in the United States, 1920-1945, Philadelphia: Temple University Press. 
Paulus, A., H. Sutherland, and P. Tsakloglou (2009), “The Distributional Impact of In-Kind Public Benefits in European Countries," EUROMOD Working Paper EM10/09 (Essex: University of Essex).

Pettit, Philip (1999), Republicanism: A Theory of Freedom and Government, Oxford Scholarship Online, DOI: 10.1093/0198296428.001.0001

Pettit, Philip (2013), "Two Republican Traditions", in A. Niederberger \& P. Schink (Eds.), Republican Democracy: Liberty, Law and Politics (pp. 169-204), Edinburgh University Press.

Piketty, Thomas (2014), Capital in the Twenty-First Century. Cambridge, MA: Belknap Press of Harvard University Press.

Piketty, Thomas, Emmanuel Saez and Gabriel Zucman (2017), "Distributional National Accounts: Methods and Estimates For The United States", The Quarterly Journal of Economics,

Plassmann, Hilke, John O'Doherty, Baba Shiv, and Antonio Rangel (2008), "Marketing actions can modulate neural representations of experienced pleasantness", 105 (3), Proceedings of the National Academy of Sciences of the United States of America, pp. 1050-1054.

Rawls, John (2007), Lectures on the History of Political Philosophy, Cambridge, Mass.: Harvard University Press.

Rich, Motoko (2012), "It's the Economy, Honey", New York Times, 11 Feb 2012, http://www.nytimes.com/2012/02/12/business/economics-of-family-life-as-taught-by-apower-couple.html

Rao A and Monroe KB (1989), “The effect of price, brand name, and store name on buyers' perceptions of product quality: An integrative review", Journal of Market Research 26, pp. $351-357$. 
Ridgeway, Cecilia L. (2014), "Why Status Matters for Inequality”, American Sociological Review, Vol. 79(1) pp. 1-16

Roine, Jesper and Daniel Waldenström (2010), “Top Incomes in Sweden over the Twentieth Century", in Anthony B. Atkinson and Thomas Piketty (Eds.), Top Incomes: A Global Perspective, Oxford: Oxford University Press.

Rollins, Judith (1985), Between Women: Domestics and their Employers, Philadelphia: Temple University Press.

Rousseau, Jean-Jacques (1762), The Social Contract and Discourses, translated with an Introduction by G.D. H. Cole (London and Toronto: J.M. Dent and Sons, 1923), facsimile downloaded from https://oll.libertyfund.org/titles/rousseau-the-social-contract-anddiscourses, 18 June 2019.

Saad-Filho, Alfredo “Overthrowing Dilma Rousseff”, Democracía Abierta, 25 March 2016, https://www.opendemocracy.net/democraciaabierta/alfredo-saad-filho/overthrowingdilma-rousseff

Sainsbury, Diane (1996), Gender, Equality and Welfare States, Cambridge University Press, Cambridge, MA.

Scanlon, Thomas M. (2003), The Difficulty of Tolerance, Cambridge: Cambridge University Press.

Sen, Amartya (1973), On Economic Inequality, Oxford: Oxford University Press.

Sen, Amartya (1979), “Utilitarianism and Welfarism”, The Journal of Philosophy, Vol. 76, No. 9, pp. 463-489.

Sen, Amartya (1984), Resources, Values and Development, Oxford: Basil Blackwell.

Sen, Amartya (1997), "From Income Inequality to Economic Inequality", Southern Economic Journal, Vol. 64, No. 2, pp. 384-401.

Singer, André (2014), “Rebellion in Brazil”, New Left Review Vol. 85, Jan-Feb, pp. 19-37. 
Smith, Adam (1776), An Inquiry into the Nature and Causes of the Wealth of Nations, republished, eds. R. H Campbell and A. S. Skinner, Oxford: Clarendon Press, 1976.

Stiglitz, J. E. (2011) 'Of the 1\%, by the 1\%, for the 1\%', Vanity Fair, May 2011, at http:/www.vanityfair.com/society/features/2011/05/top-one-percent-201105

Stiglitz, J. E., A. Sen and J.-P., Fitoussi (2009): Report by the Commission on the

Measurement of Economic Performance and Social Progress.

Tawney, R. H. (1913), 'Poverty as an industrial problem', in Memoranda on the Problems of Poverty, London, William Morris Press.

Tilly, Charles (1998), Durable Inequality, London: University of California Press.

Weber, Max (1922), Economy and Society, edited by G. Roth and C. Wittich. Translated by E. Frischoff. New York: Bedminster, 1978. Downloaded from https://archive.org/details/MaxWeberEconomyAndSociety/page/n3

Weiss, Yoram and Chaim Fershtman (1998), "Social status and economic performance: A survey", European Economic Review, Vol. 42, pp. 801-820.

Wolfe, Tom (1968), “The Ultimate Power: Seeing 'Em Jump.” New York Magazine, 23 Dec 1968 , pp. 44-47.

Veblen, Thorstein (1899), The Theory of the Leisure Class: An Economic Study of Institutions, New York: B W Huebsch, pdf downloaded from files.libertyfund.org/files/1657/1291_Bk.pdf

Zink, Caroline F., Yunxia Tong, Qiang Chen, Danielle S. Bassett, Jason L. Stein and Andreas Meyer-Lindenberg (2008), "Know Your Place: Neural Processing of Social Hierarchy in Humans", Neuron, 58(2), pp. 273-283. 


\section{Appendix: Data}

\section{Brazil}

Data for disposable incomes of top income groups are estimated from gross incomes reported in the World Wealth and Income database (wid.org) by applying personal income taxes and social security payments to 2015 gross incomes, and assuming the ratio of disposable to gross income stays constant over time. This ratio is 0.73 for the top $1 \%$ and 0.76 for percentiles 90 99. In terms of levels, this probably implies an under-estimate of net incomes (and hence of entitlements over labor) as it assumes no tax exemptions, and no capital income, which is taxed at a lower rate. Wage data were supplied by Julian Messina and his team based on the household survey PNAD, up to 2013. For 2014-15 I extended the PNAD median wage using median wage growth rates from IBGE's monthly wage survey, and the bottom $50 \%$ using the minimum wage. In Brazil $42 \%$ of non-agricultural employment is informal, and disproportionately so in the service sector (ILO 2012, Table 1), and about $10 \%$ of all employment is in agriculture, so I assume no social security contributions by employers.

\section{Mexico}

Top income data net of social security contributions but before taxes were calculated by Facundo Alvaredo. I applied contemporary personal income tax rates to estimate post-tax disposable income. Like the Brazilian case, this probably implies an under-estimate of net incomes (and hence of entitlements over labor) as it assumes no tax exemptions. Wage data are from the Encuesta Nacional de Ocupacion y Empleo, from which I calculated median wages, and average wages of the bottom 50\% of wage recipients. In Mexico 53.7\% of non-agricultural employment is informal (ILO 2012, Table 1), so as with Brazil I assume no social security contributions by employers. 


\section{Slovenia}

Data for disposable incomes of top income groups, and wages for the median and the bottom 50\%, were calculated by Filip Novokmet using EU-SILC.

\section{USA}

Data for disposable incomes of top income groups are from the World Wealth and Income database (wid.org) ${ }^{23}$ In the original data, total household income is split equally between adults in the household, denoted "adults-equal split" in wid.org. So to get the individual distribution I use the ratio of incomes measured using "equal split" to incomes measured using "individual" given in the Appendix Tables C9 and C10 of Piketty et al. (2017), which give "Post-tax income (matching national income)". This income concept is defined as disposable income plus the value of public expenditures on public goods and education, where these expenditures are allotted proportionally to disposable income. This implies that in a given year the ratio of income by "equal split" to income by individual will be the same for disposable income as it is for post-tax income. This ratio is between 1.05 and 1.07 over 1997 to 2014 . Wage data are calculated from CPS data downloaded from Flood et al (2018).

\section{Sweden}

Data for disposable incomes of top income groups were updated by Olle Hammar from Roine and Waldenström (2010); wage data are from Statistics Sweden [https://www.scb.se/en/finding-statistics/statistics-by-subject-area/labor-market/wagessalaries-and-labor-costs/salary-structures-whole-economy/]. The average wage of the bottom $50 \%$ is estimated from wage percentiles 10, 25, 50, 75 and 90 using log-normal parameterization. Cowell and Flachaire (2015: 373) report that log-normal distributions generally perform well for wage distributions, except for the right-hand tail. Since we are concerned with the bottom half of the distribution this seems an appropriate choice.

\footnotetext{
${ }^{23}$ Downloaded 19 June 2017.
} 